\title{
LEAF-CUTTING ANT FAECAL FLUID AND MANDIBULAR GLAND SECRETION: EFFECTS ON MICROFUNGI SPORE GERMINATION
}

\author{
André Rodrigues ${ }^{1,3}$; Carla D. Carletti ${ }^{1}$; Odair C. Bueno ${ }^{1,2}$; Fernando C. Pagnocca ${ }^{1,3 *}$ \\ ${ }^{1}$ Centro de Estudos de Insetos Sociais, Universidade Estadual Paulista, Universidade do Estado de São Paulo, Rio Claro, SP, \\ Brasil; ${ }^{2}$ Departmento de Biologia, Universidade Estadual Paulista, Universidade do Estado de São Paulo, Rio Claro, SP, Brasil; \\ ${ }^{3}$ Departmento de Bioquímica e Microbiologia, Universidade Estadual Paulista, Universidade do Estado de São Paulo, Rio Claro, \\ SP, Brasil.
}

Submitted: June 18, 2007; Approved: January 18, 2008.

\begin{abstract}
The mandibular gland secretion (MGS) and the faecal fluid (FF) of the leaf-cutting ant Atta sexdens rubropilosa Forel affected the spore germination of selected microfungi isolated from nests of this insect. MGS was more effective than the FF, completely inhibiting the spore germination of four out of six microfungi species.
\end{abstract}

Key words: fungus garden, microorganisms, Atta

Leaf-cutting ants (Hymenoptera: Formicidae: Attini) are wellknown social insects that maintain a complex and highly evolved mutualism with Leucoagaricus gongylophorus, a basidiomycetes fungus cultivated by these ants (20). Workers of the leaf-cutter ant genera Atta and Acromyrmex cut and carry to underground nests large amounts of fresh leaf fragments that are used as substrate for the growth of the fungal partner. Both plant material and fungal mycelium compose "the fungus garden", a sponge-like structure considered the main nutritional source for the larvae (18) and part of the energy requirements of the workers (21).

The fungus garden is an ideal environment for the development of L. gongylophorus and, under some circumstances, for detrimental microbes of the cultivated fungus $(15,19)$. Aiming to maintain the fungus garden free of competitors, leaf-cutting ants evolved a set of specific mechanisms $(2,17)$ to suppress invading microbes, that includes: the continuous cleaning of leaf fragments by workers in order to remove fungal spores and bacteria (2) and the production of antimicrobial substances by the metapleural glands $(4,14)$. In addition, recent reports have indicated that leaf-cutting ants use bacteria attached to their bodies to keep the fungus garden away of specialized parasites such as Escovopsis sp., an asexual ascomycetes fungus that negatively impacts the symbiosis (5).
Complementary defense mechanisms include the mandibular gland secretion (MGS) and the faecal fluid (FF) produced by the worker ants. Composed by secretory cells and a large reservoir the mandibular glands of ants produce alarm pheromones and compounds related to nestmate recognition $(3,7)$. Some authors also argue the MGS would be a source of antimicrobial compounds (6,9); since in vitro bioassays revealed that the MGS of Atta sexdens rubropilosa inhibited the spore germination of the plant pathogenic fungus Botrytis cinerea (10).

On the other hand, it was hypothesized that the FF, a darkcolored liquid, of leaf-cutting ants could constitute in another defense-related mechanism against alien microbes. It is known that faecal droplets containing hydrolytic enzymes (12) are deposited by workers on the fungus garden in order to promote the breaking down of plant polysaccharides; but Martin et al. (11) reported that the FF inhibits the spore germination of Penicillium sp., a microfungus commonly found in leaf-cutting ant nests (15).

Nevertheless, the antimicrobial properties of both MGS and FF were reported only for a small subset of standard microfungal and bacterial strains $(9,11)$. Thus, the aim of this study was to evaluate whether the MGS and the FF are effective in inhibiting the spore germination of microfungi species frequently isolated from nests of $A$. sexdens rubropilosa (15).

*Corresponding Author. Mailing address: Centro de Estudos de Insetos Sociais, Universidade Estadual Paulista, Av. 24-A, 1515, Bela Vista, Rio Claro, São Paulo, Brasil, 13506-900. Phone: +55 19 3526-4160; Fax: +55 19 3534-8523. E-mail: pagnocca@ rc.unesp.br 
Ants collected for the experiments originated from a 10 yearsold laboratory colony reared at $25^{\circ} \mathrm{C}$ with oat flakes and Eucalyptus sp. leaves. Using a micropipette, the FF and the MGS were collected from 350 major workers and soldiers, respectively. For the MGS collection, soldiers were first dissected in aseptic conditions under a stereomicroscope and for the FF collection workers had their gaster pressed with a sterile forceps to get the faecal droplet.

Spore suspensions $\left(6 \times 10^{6}\right.$ spores. $\left.\mathrm{mL}^{-1}\right)$ of six microfungi species isolated in a previous study on A. sexdens rubropilosa nests (15) were used in the experiments (strains are deposited at the "Coleção Brasileira de Microrganismos de Ambiente e Indústria - CBMAI", see Fig. 1 for accession numbers). The bioassays were carried out in a 96-well microtiter plate filled with $10 \mu \mathrm{L}$ of spore suspension and $50 \mu \mathrm{L}$ of Sabouraud dextrose broth supplemented with $0.05 \%$ Tween 80 and $150 \mu \mathrm{g} \cdot \mathrm{ml}^{-1}$ of chloramphenicol to which the following were added: (i) $10 \mu \mathrm{L}$ of sterile water (control); (ii) $10 \mu \mathrm{L}$ of pure FF and (iii) $10 \mu \mathrm{L}$ of pure MGS. Ten $\mu \mathrm{L}$ of cycloheximide (1000 mg. $\mathrm{mL}^{-1}$ ) was used as antifungal compound for comparison. Each treatment consisted of 10 replicates and plates were incubated at $25^{\circ} \mathrm{C}$ for $72 \mathrm{~h}$ in the dark. In order to compare treatments we have used a spore germination rate based on relative percentages of germinating spores counted in a Petroff-Neubauer hemocytometer microscope field. Since the period of time that a spore takes to germinate was different for each species, a preliminary assay was necessary to determine the optimum time to start measuring the spore germination for each microfungi in particular. The optimum time was defined as the elapsed time (in hours) in which $50 \%$ of the spores started their germination and they were as following: $24,72,14,36,30$ and 20 hours for Cunninghamella elegans, Escovopsis weberi, Fusarium solani, Metarhizium anisopliae, Syncephalastrum racemosum and Trichoderma harzianum, respectively. The results were analyzed by means of two-way ANOVA and comparisons among groups were made by the Least Square Means analysis using SAS program.

No spore germination was observed in the presence of cycloheximide; however our results revealed differential effects of FF and MGS on spore germination depending on the microfungi species $(\mathrm{p}<0.001, \mathrm{~F}=208.59$, $\mathrm{df}=5)$. Thus, about $50 \%$ of $F$. solani spores did not germinate in the presence of $\mathrm{FF}$ (Fig. 1A). On the other hand, spores of $T$. harzianum had their germination enhanced by $10 \%$ by FF when compared with the control experiment ( $\mathrm{p}<0.05$, Fig. 1A). In addition, it was observed that more than $75 \%$ of $S$. racemosum spores have germinated 10 hours before the optimum time established for the spore germination in the control treatment (Fig. 1A). Conversely, the FF had a minor inhibitory effect on spore germination of $C$. elegans and $M$. anisopliae but these differences were not statistically significant ( $p>0.05$ ). Moreover, signs of neither stimulation nor inhibition were observed on $E$. weberi spore germination in the presence of FF (Fig. 1A). It was observed that either in laboratory or natural conditions, Escovopsis strains produce a large number of asexual spores (i.e. conidia) but only a reduced proportion $(\sim 3-5 \%)$ are actually viable (Favarin, E.

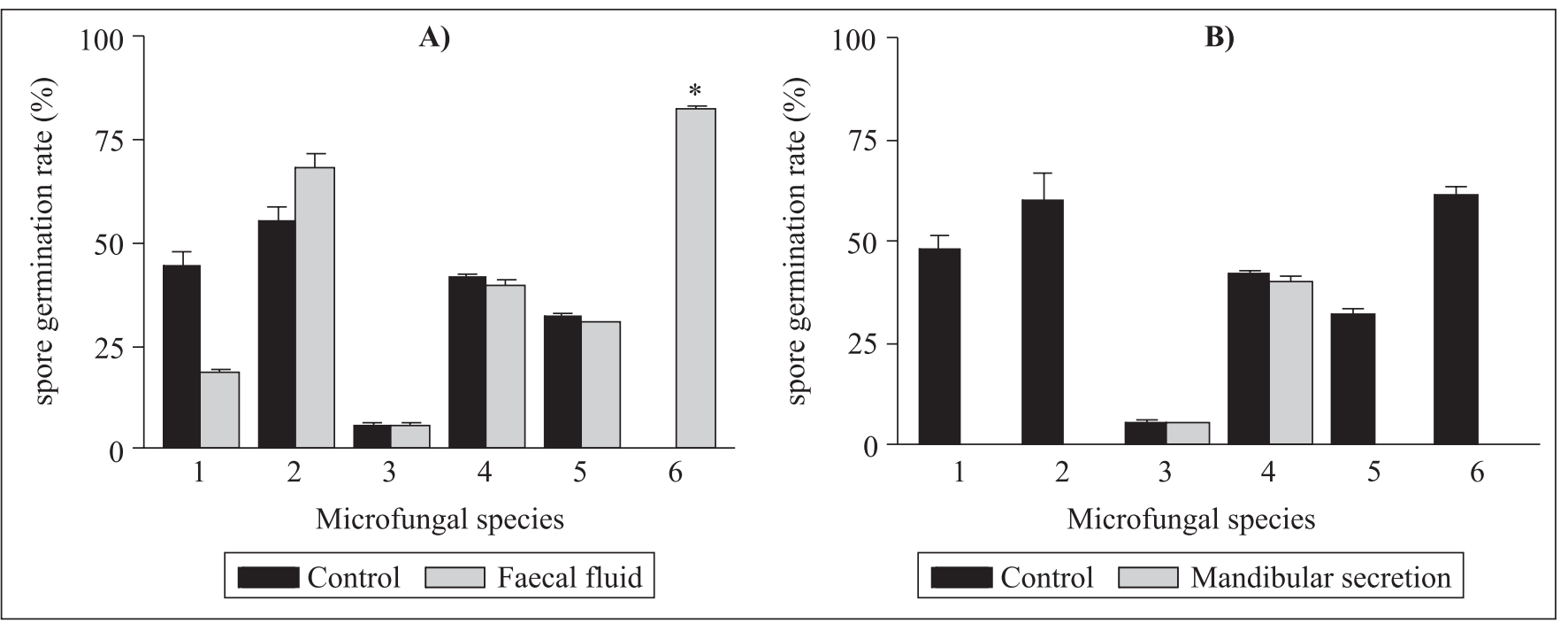

Figure 1. Spore germination rates of selected microfungi species treated with: (A) the faecal fluid and (B) the mandibular gland secretion of Atta sexdens rubropilosa. Microfungi species: (1) Fusarium solani CBMAI 874; (2) Trichoderma harzianum CBMAI 844; (3) Escovopsis weberi CBMAI 845; (4) Metarhizium anisopliae CBMAI 842; (5) Cunninghamella elegans CBMAI 843; (6) Syncephalastrum racemosum CBMAI 846. Bars indicate standard error. (*): no spore germination was observed in the control with 20 hours of incubation. See text for details. 
personal observation). This helps to explain why Escovopsis spores had a low germination rate when compared with other fungi (Fig. 1).

The leaf-cutting ant's FF is considered an adaptation for the dispersal of enzymes that promotes the development of the fungus garden. It was suggested that the FF could act as a defensive barrier against alien microfungi due the presence of hydrolytic enzymes such as chitinases (11). This is interesting because chitin is the major polysaccharide found in the cell walls of the tested microfungi (1). Probably, the reduction of spore germination of $F$. solani was due to the presence of specific chitinolytic enzymes in the FF but most of the microfungi were not affected by this fluid; conversely, some of them had their development enhanced. The causes and impact of these effects in nest integrity should be further analyzed.

The hypothesis that the MGS have a protective role against alien microorganisms is promising because this secretion completely inhibited the in vitro spore germination of C. elegans, F. solani, S. racemosum and T. harzianum but did not cause any effect on E. weberi and M. anisopliae spores (Fig. 1B). As stated by Marsaro et al. (10), the inhibition of spore germination of Botrytis cinerea was due the presence of 4-methyl 3heptanone, a well known alarm pheromone present in the MGS of several leaf-cutting ant species $(3,8)$. However, the composition of the MGS varies according to the ant caste and between nests of the same ant species (8). Soldiers of A. sexdens rubropilosa were confirmed to have 4-methyl 3-heptanone in a lesser extent than other castes (13). Thus, the observed antifungal activity could be related to other compounds present in this secretion such as chitinolytic enzymes found by Febvay et al. (6).

The fact that $E$. weberi and $M$. anisopliae spores were not affected by the MGS is evidence that ants use other defensive strategies to contain the spread of both parasites. As an example, the control of E. weberi and M. anisopliae can be achieved by means of secretion of the metapleural gland (4) and ant associated bacteria $(5,16)$ that produce compounds with pronounced antifungal activity.

The results from this study should be interpreted in the sense that the rate of spore germination was evaluated in a specific and pre-determined period of time. In this sense, our data support the hypothesized protective role of the MGS. Moreover, our results point out that under certain aspects natural enemies may overcome the elaborated defensive system of these insects; stimulating additional studies in order to develop new strategies for controlling these ants.

\section{ACKNOWLEDGEMENTS}

We would like to thank the "Conselho Nacional de Desenvolvimento Científico e Tecnológico" (CNPq) and "Fundação de Amparo à Pesquisa do Estado de São Paulo"
(FAPESP) for financial support. We are also grateful to Dr. Antônio Carlos Pião (UNESP - Rio Claro, Brazil) for the statistical analysis and Dr. Aline Silva (UESC - Ilhéus, Brazil) for comments on earlier versions of this manuscript.

\section{RESUMO}

\section{O fluído fecal e a secreção da glândula mandibular de formiga cortadeira: efeitos sobre a germinação de esporos de microfungos}

O fluído fecal (FF) e a secreção da glândula mandibular (MGS) de operárias da formiga cortadeira Atta sexdens rubropilosa Forel afetaram a germinação dos esporos de microfungos isolados dos formigueiros. MGS foi mais eficiente que FF, inibindo quatro espécies de microfungos dentre as seis estudadas.

Palavras-chaves: jardim de fungos, microrganismos, Atta

\section{REFERENCES}

1. Alexopoulos, C.J.; Mims, C.W.; Blackwell, M. (1996). Introductory mycology. John Wiley \& Sons, New York.

2. Andrade, A.P.P.; Forti, L.C.; Moreira, A.A.; Boaretto, M.A.C.; Ramos, V.M.; Matos, C.A.O. (2002). Behavior of Atta sexdens rubropilosa (Hymenoptera: Formicidae) workers during the preparation of the leaf substrate for symbiont fungus culture. Sociobiology, 40: 293-306.

3. Blum, M.S. (1969). Alarm pheromones. Annu. Rev. Entomol., 14: 57-80.

4. Bot, A.N.M.; Ortius-Lechner, O.; Finster, K.; Maile, R.; Boomsma, J.J. (2002). Variable sensitivity of fungi and bacteria to compounds produced by the metapleural glands of leaf-cutting ants. Insect. Soc., 49: 363-370.

5. Currie, C.R.; Scott, J.A.; Summerbell, R.C.; Malloch, D. (1999). Fungus-growing ants use antibiotic-producing bacteria to control garden parasites. Nature, 398: 701-704.

6. Febvay, G.; Decharme, M.; Kermarrec, A. (1984). Digestion of chitin by the labial glands of Acromyrmex octospinosus Reich (Hymenoptera: Formicidae). Can. J. Zool., 62: 229-234.

7. Hernández, J.V.; López, H.; Jaffe, K. (2002). Nestmate recognition signals of the leaf-cutting ant Atta laevigata. J. Insec. Physiol., 48: 287-295.

8. Hughes, W.O.H; Howse, P.E.; Goulson, D. (2001). Mandibular gland chemistry of grass-cutting ant: species, caste and colony variation. J. Chem. Ecol., 27: 109-124.

9. Knapp, J.J.; Jackson, C.W.; Howse, P.E.; Vilela, E.F. (1994). Mandibular gland secretions of leaf-cutting ants: role in defense against alien fungi. XII Congress of the International Union for the Study of Social Insects, Paris, p. 109.

10. Marsaro, A.L.Jr.; Della Lucia, T.M.C.; Barbosa, L.C.A.; Maffia, L.A.; Morandi, M.A.B. (2001). Efeito de secreções da glândula mandibular de Atta sexdens rubropilosa Forel (Hymenoptera: Formicidae) sobre a germinação de conídios de Botrytis cinerea Pers. Fr. Neotrop. Entomol., 30: 403-406.

11. Martin, M.M.; Gieselmann, M.J.; Martin, J.S. (1973). Rectal enzymes of attine ants. $\alpha$-amylase and chitinase. J. Insect Physiol., 19: 14091416 . 
12. Martin, M.M.; Boyd, N.D.; Gieselmann, M.J.; Silver, R.G. (1975). Activity of fecal fluid of a leaf-cutting ant toward plant-cell wall polysaccharides. J. Insect Physiol., 21: 1887-1892.

13. Nascimento, R.R.; Morgan, E.D.; Billen, J.; Schoeters, E.; Della Lucia, T.M.C.; Bento, J.M. (1993). Variation with caste of the mandibular gland secretion in the leaf-cutting ant Atta sexdens rubropilosa. J. Chem. Ecol., 19: 907-918.

14. Ortius-Lechner, D.; Maile, R.; Morgan, E.D.; Boomsma, J.J. (2000). Metapleural gland secretion of the leaf-cutter ant Acromyrmex octospinosus: New compounds and their functional significance. $J$. Chem. Ecol., 26: 1667-1683.

15. Rodrigues, A.; Pagnocca, F.C.; Bacci, M.Jr.; Hebling, M.J.A.; Bueno, O.C.; Pfenning, L.H. (2005). Variability of non-mutualistic filamentous fungi associated with Atta sexdens rubropilosa nests. Folia Microbiol., 50: 421-425.

16. Santos, A.V.; Dillon, R.J.; Dillon, V.M.; Reynolds, S.E.; Samuels, R.I. (2004). Occurrence of the antibiotic producing bacterium
Burkholderia sp. in colonies of the leaf-cutting ant Atta sexdens rubropilosa. FEMS Microbiol. Lett., 239: 319-323.

17. Schmid-Hempel, P. (1998). Parasites in social insects. Princeton University Press, New Jersey.

18. Silva, A.; Bacci, M.Jr.; Siqueira, C.G.; Bueno, O.C.; Pagnocca, F.C.; Hebling, M.J.A. (2003). Survival of Atta sexdens workers on different food sources. J. Insect Physiol., 49: 307-313.

19. Silva, A.; Rodrigues, A.; Bacci, M.Jr.; Pagnocca, F.C.; Bueno, O.C (2006). Susceptibility of the ant-cultivated fungus Leucoagaricus gongylophorus (Agaricales: Basidiomycota) towards microfungi. Mycopathologia, 162: 115-119.

20. Silva-Pinhati, A.C.O.; Bacci, M.Jr.; Hinkle, G.; Sogin, M.L.; Pagnocca, F.C.; Martins, V.G.; Bueno, O.C.; Hebling, M.J.A. (2004). Low variation in ribosomal DNA and internal transcribed spacers of the symbiotic fungi of leaf-cutting ants (Attini: Formicidae). Braz. J. Med. Biol. Res., 37: 1463-1472.

21. Weber, N.A. (1966). The fungus-growing ants. Science, 153: 587-604. 